L. Salimbeni.-The corpuscular moth of the Silkworm.

D. Ragona.-On the Ozonometric Coefficients of Humidity and Temperature.

G. Generali.-On a calculus from the Urinary Bladder of an Ox.

A. Ghiselli.-On the successful application of local Anæsthesia in a case of Lameness in a Horse caused by Rheumatism.

G. Grimelli.-Meteorological method of foreseeing and predicting. Aqueous Meteors.

F. Coppi.-Notes upon some Crystallized Fossils and upon the locality in which they are found in the Modena district.

G. Canestrini.-Researches on the Labroids of the Mediterranean. -On some ancient Skulls found in the districts of the Trentino and Venice.

P. Bonizzi.-On the Reproduction of Pholcus phalangoides, Walck.

G. Mayr.-Formicidæ novæ Americanæ collectæ a Prof. P. de Ströbel.

E. Stoehr.--Some Observations on the Natural History of Shelly Clays.

G. Canestrini.-New Italian Arachnida.

\title{
MISCELLANEOUS.
}

Considerations drawn from the study of Mole-Crickets. By Samuel H. Scudder.

Mr. S. H. Scudder stated that he had recently been studying the mole-crickets with a view to their classification, and found that they were naturally divisible into two groups. For one he retained the name of Gryllotalpa, under which all the species had formerly been grouped; to the other he applied that of Scapteriscus. These two groups were separated by the following characteristics.

In Scapteriscus the posterior margin of the sternum of the eighth abdominal segment of the $\sigma$ is produced into a stout prominent central tooth; in Gryllotalpa the margin is entire.

The mesosternal ridge of Gryllotalpa is prominent, and almost equally so throughout; that of Scapteriscus is never prominent on the anterior half of the segment, and is often limited to the posterior half, or is even obsolescent.

The fore trochanter of Scapteriscus is large; the free portion almost always equals the tibial dactyl in length, and is of about the same size at the tip as at the base; that of Gryllotalpa is proportionally small, seldom exceeding half the length of the tibial dactyl; the form is cultrate or lenticular.

Scapteriscus is furnished with only two fore tibial dactyls, both of which are moveable; Gryllotalpa has two moveable dactyls and a second pair which are immoveable.

With but few exceptions the hind femora of Scapteriscus more than equal the pronotum in length, while in Gryllotalpa they are always shorter than the pronotum. 
In Grgllotalpa the length of all the hind tarsal joints taken together seldom exceeds half the width of the pronotum, while they equal its whole width in Scapteriscus.

The hind tarsal claws of Scapteriscus are clothed with short hairs nearly to the tip ; those of Gryllotalpa have hairs only at the base.

The tegmina of Scapteriscus, with but few exceptions, cover, when at rest, two-thirds of the abdomen; in Gryllotalpa they seldom conceal more than one-half of the abdomen.

The nervures of the middle field of the tegmina in the females of Gryllotalpa are distant and rather irregular, somewhat resembling those of the males; in Scapteriscus they are approximate, regular, and straight.

The anal cerci are longer than the pronotum in Gryllotalpa; shorter in Scapteriscus.

Finally, the ninth and, sometimes, the eighth abdominal segments are furrished above, in Gryllotalpa, with two transverse lateral rows of long hairs directed inward, as if to keep the long folded wings in place; these are absent from Scapteriscus, where the wings are equally long and similarly folded.

Only one species of Scapteriscus has been found without the limits of South and Central America, and that (occurring in a single instance in Europe) must undoubtedly be considered an emigrant from the same warm regions; the members of the genus Gryllotalpa, on the contrary, are found throughout the whole world, not excluding Central and South America.

Comparing these two genera with their nearest allies, Tridactylus, Cylindrodes, \&c., we find great and striking differences-differences which are extraordinary compared with those which divide Scapteriscus and Gryllotalpa: the comparatively simple fore tibiæ and the abnormal appendages which supplant the hind tarsi in Tridactylus, the abbreviated legs fitting into cavities in the body, and the absence of articulated appendages at the extremity of the abdomen, in Cylindrodes - these characteristics are far more important than the sexual sculpture of the abdomen, the ultimate neuration of the tegmina, the length of the legs, the contour of the trochanters, or the digitation of the tibiæ, which separate Scapteriscus and Gryllotalpa.

The facts cited above present two features which bear upon the question of the origin of species.

First: these little mole-crickets, so unique in their structure as to be widely separated from their nearest allies, are spread uniformly over the whole surface of the globe; but few species occur in any one place, and at least one is found in every temperate or hot region.

Now, if species originate or change from physical causes, or by "Natural Selection," why is it that under every physical condition and surrounded by every variety of antagonism possible in their habitat, this same unique structural form has sprung up all over the globe?

Again, how can such theories account for another feature (common, indeed, to all natural groups), that it is not one striking characteristic which separates Scapteriscus and Gryllotalpa, and which 
"Natural Selection" might have seized upon, with reference to some special benefit, but a combination of features which have no apparent dependence upon each other, correlated, but not necessarily connected? Why should "Natural Selection," altering for its own purpose the palm of the four-fingered mole-cricket into that of the two-fingered species in South America, or developing in South America, from some previous synthetic form of mole-cricket, both the present four-fingered and two-fingered species, and in other parts of the world the four-fingered species only (destroying at the same time the primæval form all over the surface of the globe), at the same time place rows of hairs on the hinder part of the abdomen of the tetradactylate group, and none on that of the didactylate? or make the veins of the tegmina of the $q$ of one group distant and irregular, and those of the other straight and approximate? Why furnish the eighth abdominal segment of the $\delta$ of one with a projecting tooth, and deprive those of the others of such a prominence? Why give one long and the other short anal cerci, or clothe the hind tarsal nails of one with short hairs and leave the other naked? What have these features to do with the differences of structure we have mentioned in the palm-shaped fore leg, or in the length of the hind leg? These and similar difficulties, arising on every hand, seem to attend every derivative theory of the origin of species.Silliman's American Journal, November 1868.

\section{The Finner Whale of the North Sea.}

M. G. O. Sars, the son of the well-known Professor of Christiania, has published a very interesting paper on the individual variations of the Finner Whale, in which he has compared, and formed tables of the measurements of, the eighteen specimens of the Finner Whale of the North Sea described by Sibbald, Müller, and other zoologists. He comes to the conclusion that there are six species, viz. Balcenoptera musculus, B. Carolina, B. gigas, B. laticeps, B. rostrata, and Megaptera longimana.

\section{The Scrag Whale of Dudley.}

Mr. Cope, in the 'Journal of the Academy of Sciences of Philadelphia,' 1868 , p. 222, describes the bones of an imperfect specimen of the Scrag Whale that was described by Dudley in 1725 , but has not been seen by any naturalist since that period. It has a smooth throat, like the Right Whale; it has only four slender fingers at the carpus, and the bladebone of the Finner or Balcenoptera. He proposes for it a new genus named Agaphelus. It is to be regretted that the cranium, cervical and dorsal vertebræ, and first ribs were carried away by the tide before the skeleton was examined. It proves a most interesting genus, intermediate in structure between the Right Whale and the Finner. It does not prove the truth of the theory of Capt. Atwoods, that the Scrag Whales "were probably specimens of the Right Whale that had been left by their mothers 


\section{$2 \mathrm{BHL}$ Biodiversity Heritage Library}

Scudder, Samuel Hubbard. 1869. "Considerations drawn from the study of mole-crickets." The Annals and magazine of natural history; zoology, botany, and geology 3, 162-164. https://doi.org/10.1080/00222936908695900.

View This Item Online: https://www.biodiversitylibrary.org/item/79672

DOI: https://doi.org/10.1080/00222936908695900

Permalink: https://www.biodiversitylibrary.org/partpdf/62488

\section{Holding Institution}

Smithsonian Libraries

\section{Sponsored by}

Smithsonian

\section{Copyright \& Reuse}

Copyright Status: Public domain. The BHL considers that this work is no longer under copyright protection.

This document was created from content at the Biodiversity Heritage Library, the world's largest open access digital library for biodiversity literature and archives. Visit BHL at https://www.biodiversitylibrary.org. 